\title{
Seasonal variations in the trophic relationship between the scyphomedusa Aurelia aurita s.l. and mesozooplankton in a eutrophic brackish-water lake, Japan
}

\author{
Chang-hoon Han, Masato KaWahara \& Shin-IChi Uye* \\ Graduate School of Biosphere Science, Hiroshima University, 4-4 Kagamiyama 1 Chome, Higashi-Hiroshima 739-8528, Japan
}

Received 4 July 2008; Accepted 29 October 2008

\begin{abstract}
The seasonal variations in trophic relationship between the moon jelly Aurelia aurita s.1. and mesozooplankton were investigated in a brackish-water lake, Honjo District, Japan from June 2005 to August 2006. The medusae occurred abundantly (average abundance and biomass: 0.55 medusae $\mathrm{m}^{-3}$ and $58.8 \mathrm{mg} \mathrm{C} \mathrm{m}^{-3}$, respectively) during warm seasons (i.e. June-November, 2005), but were very scarce or absent during the remaining seasons. The mesozooplankton biomass fluctuated from 1.3 to $150 \mathrm{mg} \mathrm{C} \mathrm{m}^{-3}$ (overall average: $60.5 \mathrm{mg} \mathrm{C} \mathrm{m}^{-3}$ ) irrespective of the medusa biomass variation. Mesozooplankton were preyed upon by medusae almost non-selectively; the small copepod Oithona davisae and bivalve larvae were the predominant prey, comprising 52-99\% (average: $85 \%$ ) of the gastric pouch contents. The medusa population ingestion rate on mesozooplankton varied from 0.11 to $12.8 \mathrm{mg} \mathrm{Cm}^{-3} \mathrm{~d}^{-1}$, which corresponded to 0.6 to $29 \%$ of the mesozooplankton biomass per day and to 1.6 to $47 \%$ of mesozooplankton daily production rate. A. aurita medusae were certainly a key component of the zooplankton community, but they did not exert any significant top-down control as to suppress mesozooplankton biomass in this eutrophic lake.
\end{abstract}

Key words: Aurelia aurita, Japan, mesozooplankton, predation impact, seasonal occurrence

\section{Introduction}

The ecological importance of large gelatinous carnivorous zooplankton such as cnidarians and ctenophores has been increasingly recognized, since their unusual aggregations and population increases have been reported frequently in many parts of the world's ocean in recent decades (Arai 2001, Mills 2001, Brodeur et al. 2002, Purcell 2005, Kawahara et al. 2006, Purcell et al. 2007). Previous studies suggest that the abundance of such jellyfish can be a key factor in regulating the trophic structure of marine plankton communities; when they occur abundantly, their predation impact may be so intensive as to affect the population size and species composition of the plankton communities (Lindahl \& Hernroth 1983, Olesen 1995, Schneider \& Behrends 1998, Pagès et al. 2001). At the same time, jellyfish also reduce fish standing stocks, either by direct predation on fish eggs and larvae or by competing with planktivorous fish and fish larvae for available zooplankton prey (Möller 1980, Purcell \& Arai, 2001, Hansson et al. 2005). In addition, jellyfish hamper fishing activity by clogging

Corresponding author: Shin-ichi Uye; E-mail, suye@hiroshima-u.ac.jp and bursting fishing nets, and cause problems to coastal power plants by blocking cooling water intakes (Kuwabara et al. 1969, Rajagopal et al. 1989, Purcell et al. 2007).

In Japanese coastal waters, like many other coastal waters, the moon jelly Aurelia aurita s.l. Linnaeus is the most common and abundant scyphozoan species (see Dawson 2003, Dawson \& Martin 2001 for sibling species), and it is particularly abundant in eutrophic waters such as Tokyo Bay and the Inland Sea of Japan. In Tokyo Bay, the mass occurrence of A. aurita medusae began in the 1960s, when associated problems of clogged screens of power plant seawater intakes were reported (Kuwabara et al. 1969, Yasuda, 1983). Since then, A. aurita has become the most dominant species in the zooplankton community (Omori et al. 1995) and exerts high predation pressure, equivalent to 5 to $162 \%$ of mesozooplankton biomass per day in spring and summer (Kinoshita et al. 2006). In the Inland Sea of Japan, the increase in A. aurita population became significant in the 1990 s, when both increasing water temperature, particularly in winter, and decreasing of zooplanktivorous fish populations were prominent (Uye et al. 2003, Uye \& Ueta 2004). In Ondo Straight, a central part of the Inland Sea of Japan, 
the average biomass of $A$. aurita $\left(66.0 \mathrm{mg} \mathrm{C} \mathrm{m}^{-3}\right)$ was much higher than the micro- and mesozooplankton biomass (average: $23.7 \mathrm{mg} \mathrm{C} \mathrm{m}^{-3}$ ) and its predation impact was equivalent to $26 \%$ of zooplankton biomass per day from May to August (Uye \& Shimauchi 2005).

Honjo District is an enclosed shallow brackish-water lake (area: $16.2 \mathrm{~km}^{2}$, average depth: $5.1 \mathrm{~m}$ ) in the northern part of Lake Nakaumi, Shimane Prefecture (Fig. 1). The Honjo District was separated from other waters by construction of a bank in 1981, but with connections via two narrow inlets so that the water exchange between the Honjo District and the Lake Nakaumi is limited (daily exchange rate: $2.26 \%$ of water volume of the Honjo District, Koike et al. 1999). Frequent mass occurrences of $A$. aurita medusae during summer were reported by local fishermen after the embankment, but no research has been conducted on their seasonal population dynamics in the Honjo District. Meanwhile, this eutrophic lake harbors one of the world's highest mesozooplankton biomasses (annual average: $71 \mathrm{mg} \mathrm{C} \mathrm{m}^{-3}$, Uye et al. 2004), and hence it is our prime aim to understand the prey and predator relationship between mesozooplankton and $A$. aurita medusae. We investigated the seasonal variations in abundance, biomass, gut contents and population ingestion rate of $A$. aurita medusae, together with mesozooplankton abundance, taxonomic composition, biomass and production rate.

\section{Materials and Methods}

\section{Aurelia aurita medusa abundance, biomass and gut con- tents}

Prior to the initiation of our regular samplings, we conducted a sighting survey on the geographical distribution of A. aurita medusae by running a boat along 3 cross transects of the Honjo District. Since we encountered aggregated medusae most often in the central part of the lake and very few near the shore, we set up a sampling area (approximate diameter: $3 \mathrm{~km}$ ) in the central Honjo District (Fig. 1) during our investigation (at ca. 2-week intervals) from June 2005 to August 2006. On each sampling occasion, surface and bottom (depth: ca. $6 \mathrm{~m}$ ) water temperatures, salinities and dissolved oxygen concentrations were measured by a multiple water checker (Horiba, U-20). To lessen the sampling variance due to heterogeneous distribution (see Results), medusae were caught by 5 to 7 horizontal tows of a net (0.6 m mouth diameter, $2.0 \mathrm{~m}$ length, $505 \mu \mathrm{m}$ mesh size and fitted with Rigosha flowmeter) at 1-3 m depth at $1.0-1.5 \mathrm{~m}$ $\mathrm{s}^{-1}$ for 3-5 minutes. Total wet weight and numbers of medusae caught by each tow were determined, and the bell diameter and wet weight were measured for specimens caught during separate tows.

Wet, dry and carbon weights were determined for medusae collected in August 2005. Medusae were transported alive to the laboratory in $20 \mathrm{~L}$ containers. After rinsing with distilled water and blotting, wet weight was measured. Dry weight was then measured after drying in an electric oven at $60-65^{\circ} \mathrm{C}$ for $4-6$ days until constant weight was reached. Carbon contents of $15-22 \mathrm{mg}$ aliquots of pulverized dried medusa were determined using a $\mathrm{CHN}$ analyzer (Yanagimoto, MT-3) with antipyrine as the standard.

On each sampling date, 5 to 10 medusae were collected by a scoop net, and were individually preserved in $10 \%$ formalin lake-water solution. Within several days of sampling, the gastric pouch was dissected and the food contents removed from the gastric filaments by using a jet of tap water. The gut contents in the wash were retained with a $40 \mu \mathrm{m}$ sieve and examined under a dissecting microscope. Appropriate body length of zooplankters (e.g. prosome length for copepod copepodites, body length for copepod nauplii, cladocerans and polychaete larvae, body width for bivalve

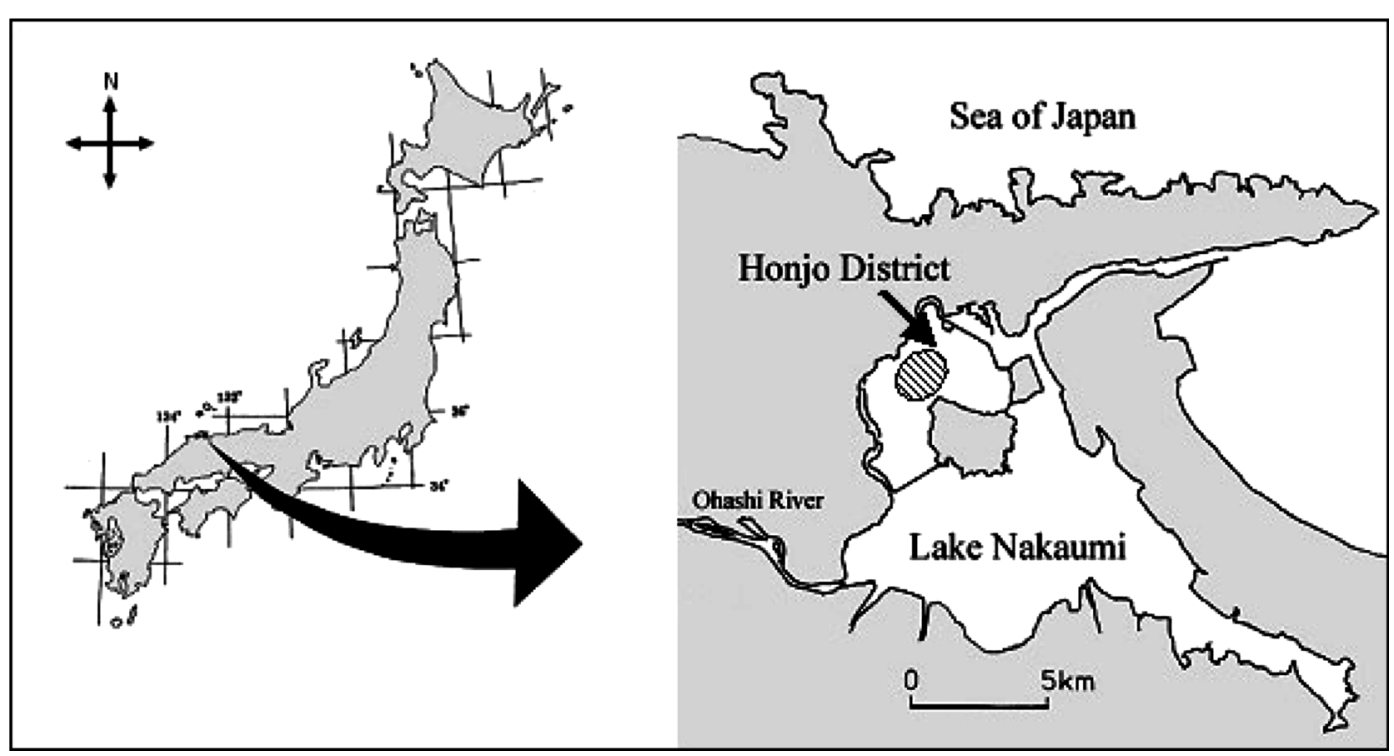

Fig. 1. Sampling site of Aurelia aurita medusae and mesozooplankton (shaded) in Honjo Disrict, Shimane Prefecture, Japan. 
larvae, see Uye 1982) were measured with a video micrometer (Mitani, WinRoof) and automatically converted to carbon weights using predetermined length-weight regressions (see Uye \& Shimazu 1997 for details).

\section{Mesozooplankton abundance, biomass and production rate}

Mesozooplankton samples were collected by vertical hauls of a plankton net $(25 \mathrm{~cm}$ mouth diameter, $80 \mu \mathrm{m}$ mesh size) from the bottom to the surface and immediately fixed with $5 \%$ formalin lake-water solution. Because of the relatively homogeneous distribution of mesozooplankton in the Honjo District (overall average of variance of their abundance among 7 samples: 22\%) found in a previous study (24 sampling occasions for two years, Uye et al. 2004), a single sample was examined on each occasion. The sample was split into $1 / 16-1 / 32$ subsamples with a Motoda box splitter, from which at least 200 specimens were identified and counted under a dissecting microscope. Their appropriate body lengths were measured and converted to carbon weights, as described above. The production rate of each taxonomic group $\left(P, \mathrm{mg} \mathrm{C} \mathrm{m}^{-3} \mathrm{~d}^{-1}\right)$ was estimated based on its biomass $\left(B, \mathrm{mg} \mathrm{C} \mathrm{m}^{-3}\right)$ and experimentally determined specific growth rates $\left(g, \mathrm{~d}^{-1}\right)$ (see Table 1 of Uye \& Shimazu 1997):

$$
P=B \times g .
$$

Summation of this for all taxonomic groups gives the mesozooplankton community production rate $(C P$, $\left.\mathrm{mg} \mathrm{C} \mathrm{m}{ }^{-3} \mathrm{~d}^{-1}\right)$ :

$$
C P=\Sigma P .
$$

\section{Feeding selectivity and predation impact}

The feeding selectivity of $A$. aurita was determined based on the Chi-square $\left(\chi^{2}\right)$ method comprising of two $\times$ two configured comparisons between the average number of each prey taxon in the gastric pouch and corresponding number in the ambient water (see Pearre 1982 for details) as has been commonly used in many jellyfish prey selectivity studies (Graham \& Kroutil 2001, Purcell \& Sturdevant 2001, Sullivan et al. 1994). Selectivity, C, is given by:

$$
C= \pm\left(\chi^{2} / n\right)^{1 / 2}
$$

where $n$ is the total number of a given prey taxon both in the medusa and in the water.

The A. aurita population ingestion rate on mesozooplankton was estimated by:

$$
P I R=24 \times G C \times D T^{-1} \times N
$$

where PIR is the population ingestion rate $\left(\mathrm{mg} \mathrm{C} \mathrm{m}^{-3} \mathrm{~d}^{-1}\right)$, $G C$ is the average carbon weight of gut contents $\left(\mathrm{mgC}\right.$ medusa $^{-1}$ ), $N$ is medusa abundance $\left(\right.$ medusae $\mathrm{m}^{-3}$ ) and $D T$ is digestion time (h). The digestion time was not measured but assumed to be $1.0 \mathrm{~h}$ according to the previous studies by Ishii \& Tanaka (2001) and Uye \& Shimauchi (2005), because of similar prey taxa (i.e. Oithona davisae 
Ferrari \& Orsi, Acartia omorii Bradford, bivalve larvae and gastropod larvae), medusa bell diameter: (range: 10-25 cm) and temperature (range: $18-22^{\circ} \mathrm{C}$ ) in these studies.

\section{Results}

\section{Environmental parameters}

Temperature fluctuated greatly from 3.2 to $30.7^{\circ} \mathrm{C}$ at the surface and from 3.2 to $28.3^{\circ} \mathrm{C}$ at the bottom (Fig. 2a). Salinity varied from 12 to 24 at the surface and from 14 to 25 at the bottom with overall averages of 19.8 and 20.8, respectively (Fig. 2b). Dissolved oxygen concentration was usually saturated $\left(>7.5 \mathrm{mg} \mathrm{O}_{2} \mathrm{~L}^{-1}\right)$ at the surface, but hypoxic at the bottom (minimum: $0.5 \mathrm{mg} \mathrm{O}_{2} \mathrm{~L}^{-1}$ ) during summer (Fig. 2c).

\section{Mesozooplankton abundance, biomass and production rate}

Mesozooplankton abundance showed considerable fluctuations with season, occurring more abundantly from June to October (average: $23.4 \times 10^{4}$ ind. $\mathrm{m}^{-3}$ ) than in the remain-

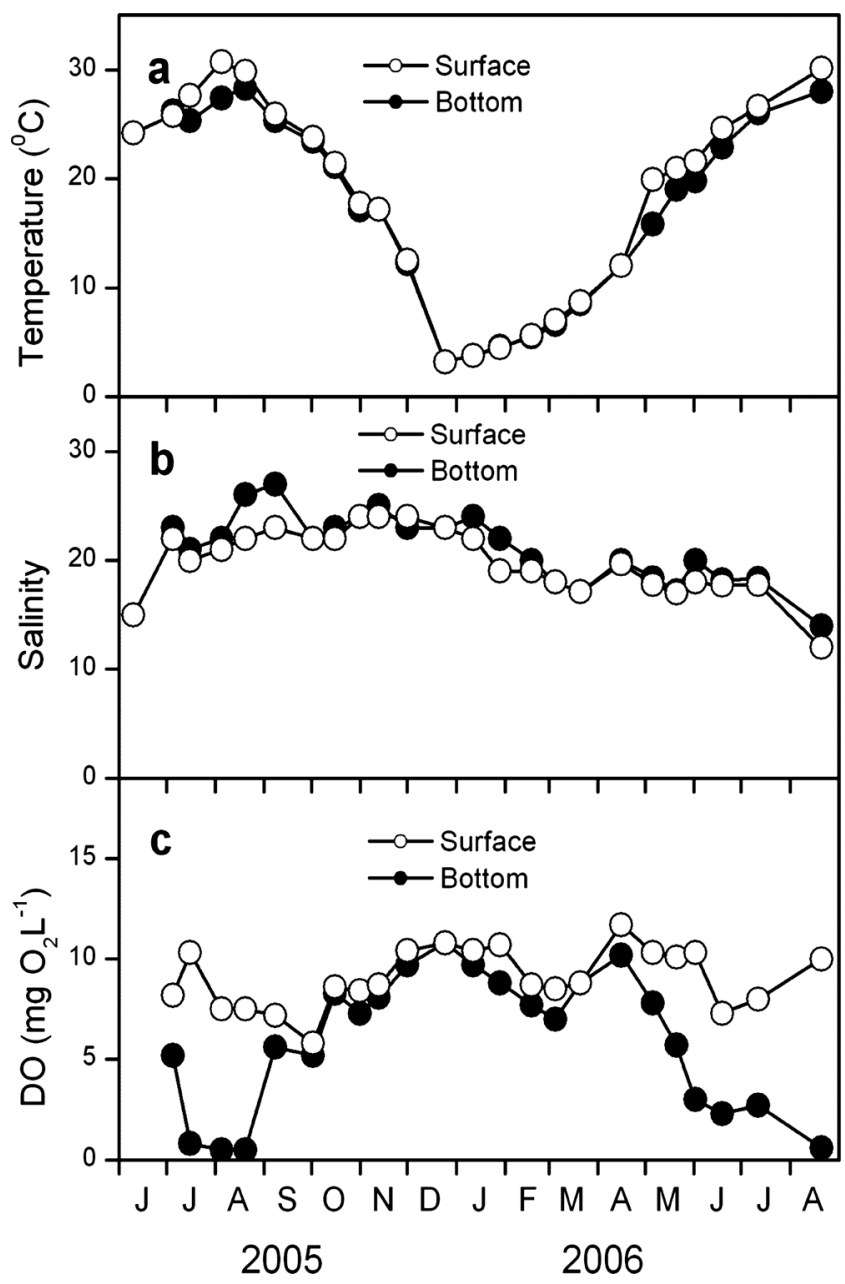

Fig. 2. The seasonal variations in surface and bottom $(6 \mathrm{~m})$ temperature (a), salinity (b) and dissolved oxygen (c) concentration in Honjo District. ing periods (average: $4.4 \times 10^{4}$ ind. $\mathrm{m}^{-3}$ ) (Fig. 3a). The annual peak abundance was recorded on 5 August 2005 $\left(44.4 \times 10^{4}\right.$ ind. $\left.\mathrm{m}^{-3}\right)$ and on 12 July $2006(73.3 \times$ $10^{4}$ ind. $\mathrm{m}^{-3}$ ).

In terms of biomass, mesozooplankton also fluctuated markedly from 1.3 to $150 \mathrm{mg} \mathrm{C} \mathrm{m}^{-3}$ over the study period (Fig 3b). Largely according to the seasonal numerical variation, the biomass was also high from June to October (average: $70 \mathrm{mg} \mathrm{C} \mathrm{m}^{-3}$ ) with prominent peaks on 5 July (116 $\left.\mathrm{mg} \mathrm{C} \mathrm{m}{ }^{-3}\right)$ and on 16 October $\left(150 \mathrm{mg} \mathrm{C} \mathrm{m}^{-3}\right)$ in 2005 and on 20 August $\left(128 \mathrm{mg} \mathrm{C} \mathrm{m}^{-3}\right)$ in 2006 . These biomass peaks were composed primarily $(65-99 \%)$ of the small
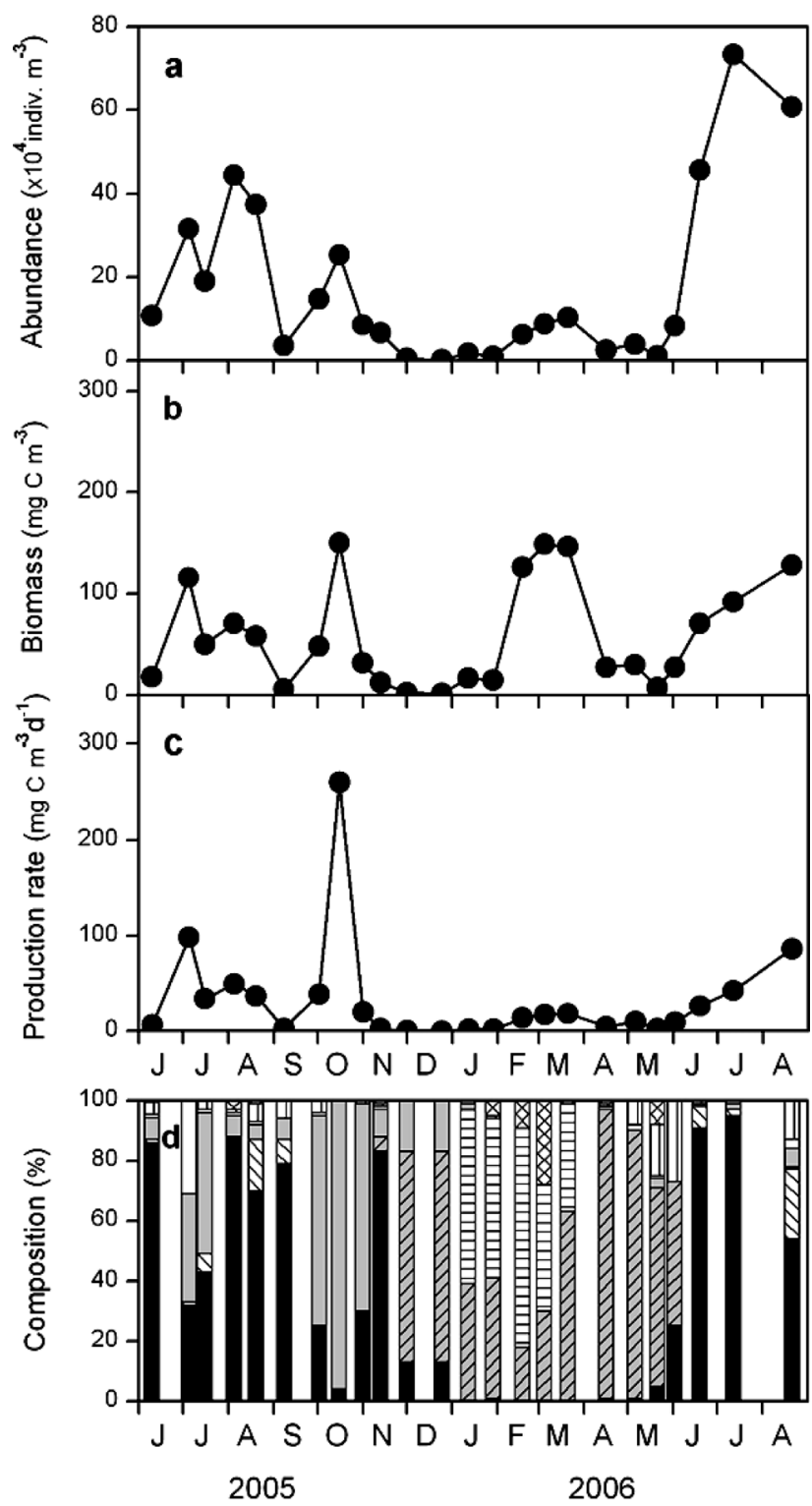

Oithona davisae $\mathrm{II}$ Acartia sinjiensis ZIय Acartia hudsonica $\square$ Eurytemora pacifica $\square$ Bivalve larvae $\square$ Gastropod larvae पII Polychaete larvae $x$ Others

Fig. 3. The seasonal variations in abundance (a), biomass (b), production rate (c) and biomass-based taxonomic composition of mesozooplankton (d) in Honjo District. 
copepod Oithona davisae and bivalve larvae (Fig. 3d).

Mesozooplankton production rate varied from 2.2 to $260 \mathrm{mg} \mathrm{C} \mathrm{m}^{-3} \mathrm{~d}^{-1}$ (Fig. 3c). As a result of positive temperature effects on the specific growth rate, the production rate tended to be higher relative to biomass during warm seasons. An extremely high production rate on 16 October 2005 was attributed to the dominance of small-sized bivalve larvae.

\section{Aurelia aurita medusa abundance, biomass and gut con- tents}

Measurements of $600 \mathrm{~A}$. aurita specimens from the Honjo District gave the following relationship between wet weight $(W W, \mathrm{~g})$ and bell diameter $(B D, \mathrm{~cm})$ (Fig. 4):

$$
W W=0.089 B D^{2.70} \text {. }
$$

Dry weight and carbon contents were measured for 18 medusae, with wet weights ranging from 13 to $78 \mathrm{~g}$. Average dry weight was $2.6 \%(\mathrm{SD}=1.1 \%)$ of wet weight, and average carbon weight was $4.8 \% \quad(\mathrm{SD}=2.3 \%)$ of dry weight. There was no significant size-dependent difference in these relative weights. Hence, the average wet:dry: carbon weight ratio for $A$. aurita medusae from the Honjo District was $100: 2.6: 0.13$, which was used for converting wet weight biomass to carbon biomass.

Although we repeated 5-7 net tows at randomly selected locations in the central Honjo District to alleviate the sampling variance (overall average: $60 \%$ ), the sample size of each tow differed greatly, particularly in summer of 2005 when medusae were often in patchy aggregations. In an extreme case on 5 August 2005, one towed sample contained 193 medusae but the next one contained only 2 medusae. Hence, the sampling variance among 7 tows on this date

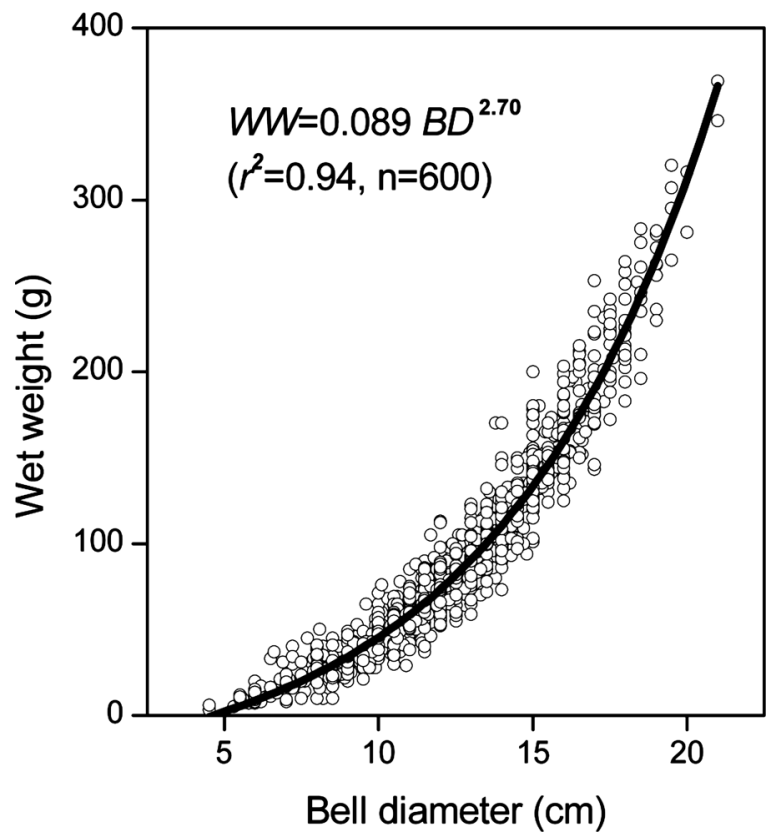

Fig. 4. Relationship between bell diameter and wet weight of Aurelia aurita caught in Honjo District. was as large as $144 \%$.

The abundance of $A$. aurita medusae increased from 0.29 medusae $\mathrm{m}^{-3}$ in June, peaked on 20 August (1.33 medusae $\mathrm{m}^{-3}$ ) and then suddenly declined on 8 September 2005 (Fig 5a). A strong typhoon, No. 14 (maximum wind speed in Shimane Prefecture: $97 \mathrm{~km} \mathrm{~h}^{-1}$ ), passed on 6 September. Although only a few medusae were caught by our regular net samplings on 8 September, our scuba diving observations revealed that a large number of medusae were concentrated in the well-aerated bottom layer (Fig. 2c). After this sudden decline, the abundance recovered to 0.59 medusae $\mathrm{m}^{-3}$ in October and then disappeared until resurgence in June 2006 (Fig. 5a). The medusa population was much smaller in 2006 (maximum abundance: 0.12 medusae $\mathrm{m}^{-3}$ ) than in 2005 (Fig. 5a).

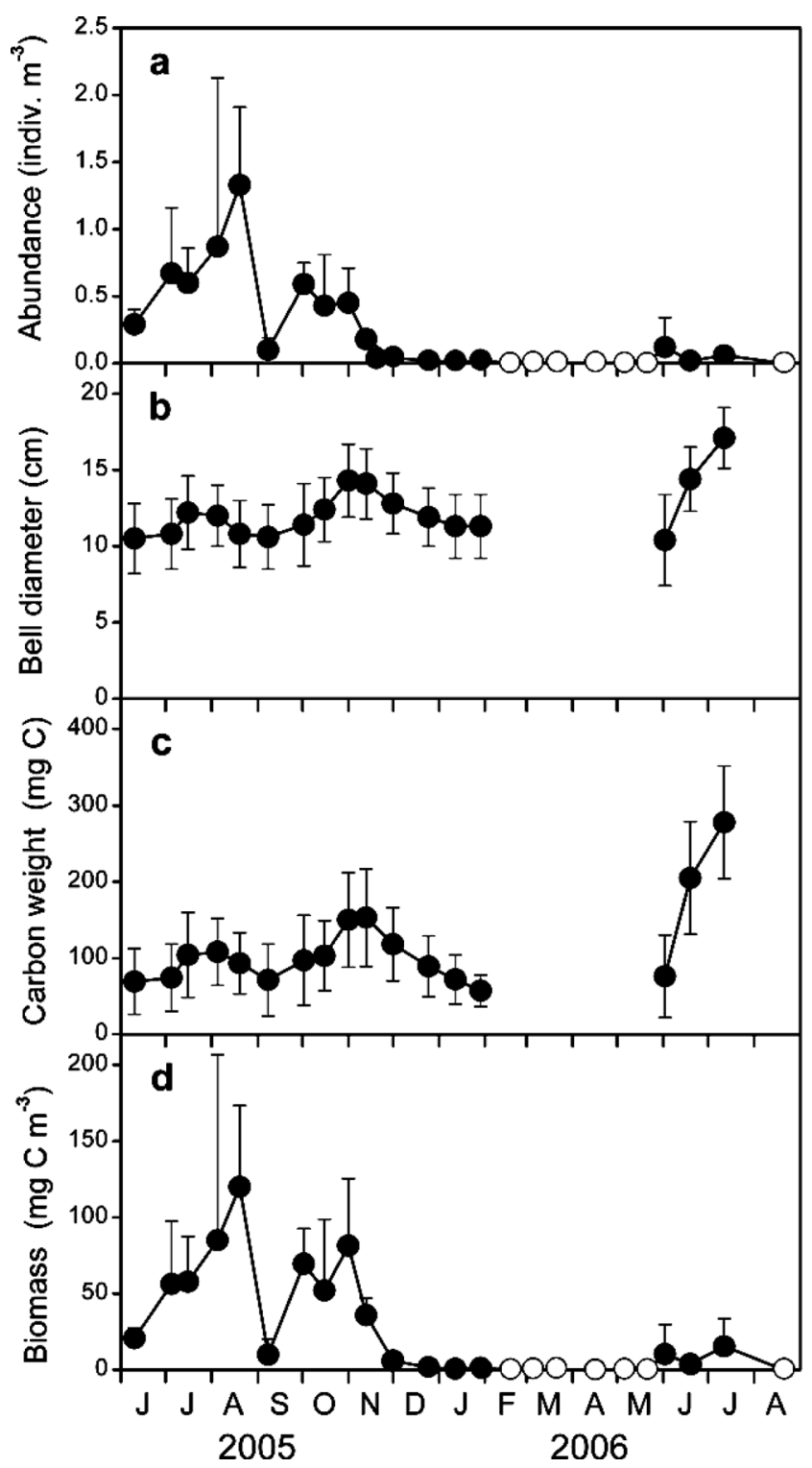

Fig. 5. The seasonal variations in abundance (a), bell diameter (b), carbon weight (c) and biomass (d) of Aurelia aurita in Honjo Distirct. Vertical lines denote SD. Open circles indicate zero. 
In 2005, the size of medusae was smallest in June (average bell diameter and carbon weight: $10.5 \mathrm{~cm}$ and $20.6 \mathrm{mg}$ $\mathrm{C}$, respectively), and gradually increased until November, when average bell diameter and carbon weight was $14.3 \mathrm{~cm}$ and $153 \mathrm{mg} \mathrm{C}$, respectively (Fig. 5b, c). There were no significant changes in the frequency distributions of medusa bell diameter in 2005 and individual cohorts could not be identified. The growth of medusae was, however, clearly traced during June and July 2006, when the average bell diameter and carbon weight increased from 10.4 to $17.1 \mathrm{~cm}$ and from 60.3 to $278 \mathrm{mg} \mathrm{C}$, respectively.

The pattern of seasonal variation in medusa biomass was similar to that of abundance; increasing from 20.6 $\mathrm{mg} \mathrm{C} \mathrm{m}{ }^{-3}$ in June to $120 \mathrm{mg} \mathrm{C} \mathrm{m}^{-3}$ in August then decreasing to $35.7 \mathrm{mg} \mathrm{C} \mathrm{m}^{-3}$ in November (Fig. $5 \mathrm{~d}$ ). The average biomass between June and November was $58.8 \mathrm{mg} \mathrm{C} \mathrm{m}^{-3}$. The average medusa biomass in June and July 2006 was $10.0 \mathrm{mg} \mathrm{C} \mathrm{m}^{-3}$.

The daily ingestion rate varied markedly from 0.06 to $29.8 \mathrm{mg} \mathrm{C}$ medusa ${ }^{-1} \mathrm{~d}^{-1}$ in 2005 (Fig. 6a). The highest ingestion rate was recorded on 16 October 2005, when prey biomass and production rate were also highest (Fig. 3a).

The gut content examination revealed that $A$. aurita medusae ingested all the mesozooplankton taxa present in the Honjo District. The small copepod $O$. davisae and bivalve larvae were the most important prey items (Fig. 6b),
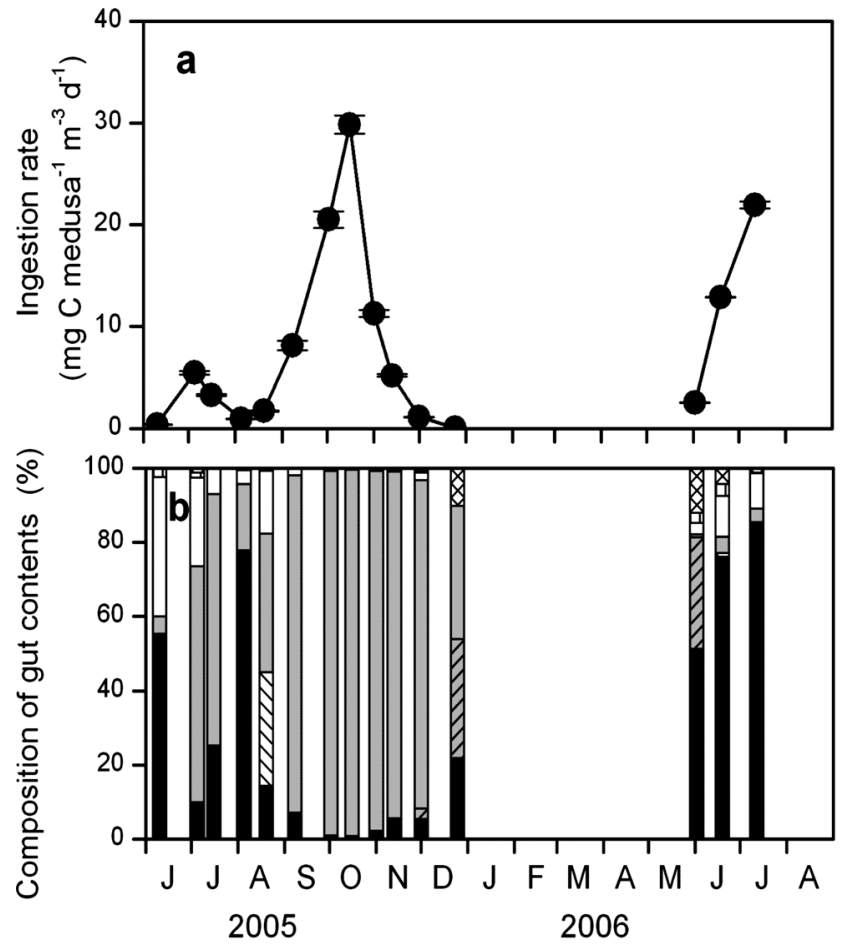

Oithona davisae 11 Acartia sinjiensis $Z$ ZIय Acartia hudsonica Eurytemora pacifica $\square$ Bivalve larvae $\square$ Gastropod larvae एس] Polychaete larvae Others

Fig. 6. The seasonal variations in ingestion rate (a) and carbon biomass composition of gut contents (b) of Aurelia aurita in Honjo District. Vertical lines donote SD.

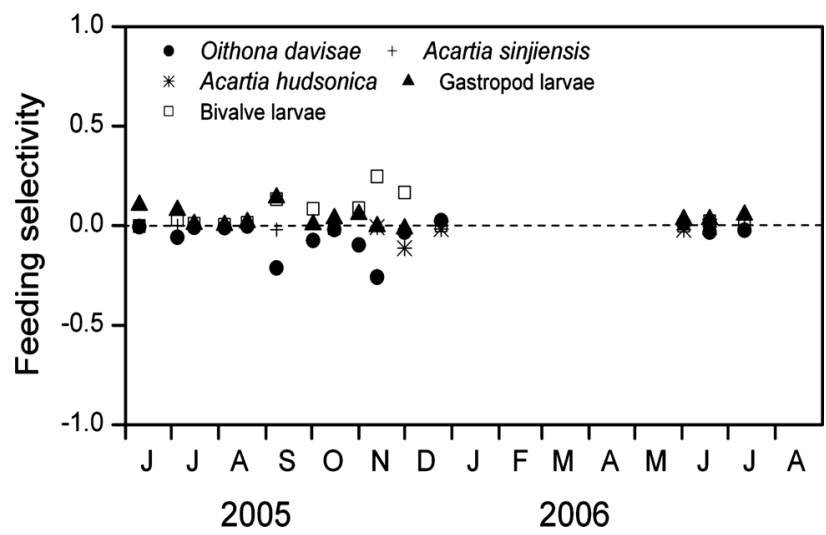

Fig. 7. The seasonal variations in feeding selectivity of Aurelia aurita estimated from gut contents and ambient mesozooplankton in Honjo District.

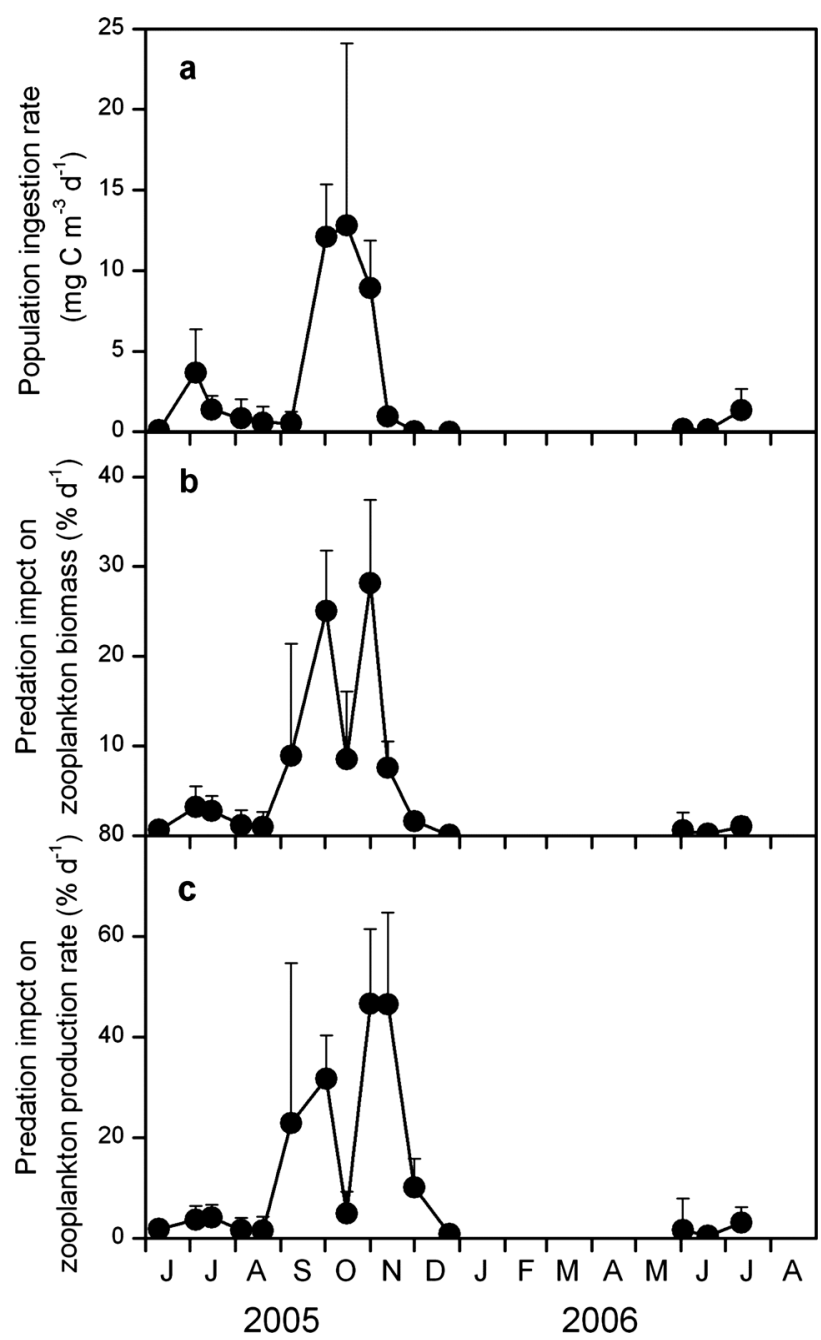

Fig. 8. The seasonal variations in population ingestion rate (a), predation impact on mesozooplankton biomass (b) and predation impact on mesozooplankton production rate (c) of Aurelia aurita in Honjo District. Vertical lines denote SD. 
accounting for 52 to $99 \%$ (average: $85 \%$ ) of the gut contents, reflecting their dominance in the plankton. Other major prey taxa were copepods (Acartia hudsonica Pinhey and $A$. sinjiensis Mori) and gastropod larvae.

The feeding selectivity of medusae was determined for 5 prey categories, i.e. A. hudsonica, A. sinjiensis, O. davisae, bivalve larvae and gastropod larvae. It ranged from -0.26 for $O$. davisae to 0.25 for bivalve larvae, both recorded on 13 November, but usually stayed near zero (Fig. 7), indicating that $A$. aurita medusae fed on mesozooplankton prey largely non-selectively.

\section{Aurelia aurita population impact on mesozooplankton}

The ingestion rate of the population of medusae on the mesozooplankton community varied from 0.11 to 12.8 $\mathrm{mg} \mathrm{C} \mathrm{m}^{-3}$ from June to November (Fig. 8a), which corresponded to 0.6 to $29 \%$ (average: $8.9 \%$ ) of the mesozooplankton biomass per day (Fig. 8b), and to 1.6 to $47 \%$ (average: $13.0 \%$ ) of the mesozooplankton daily production rate (Fig. 8c).

\section{Discussion}

The present study demonstrated the seasonality of the $A$. aurita medusa population in the Honjo District for the first time, where the population culminated during warm seasons (Fig. 5a), similar to that observed in other Japanese waters such as Lake Hamana (Kuwabara 1969), Urazoko Bay (Yasuda 1983), Tokyo Bay (Omori et al. 1995) and the Inland Sea of Japan (Uye \& Shimauchi 2005). In 2005, medusae already occurred before our survey started and they seemed to grow relatively slowly to the maximum size in autumn. In 2006, the resurgence of medusae occurred in June after the disappearance of the population in the preceding winter and spring. This indicates that a new medusa generation might start in spring, as has been commonly observed in other Japanese coastal waters (Yasuda 1969, Miyake et al. 1997, Watanabe \& Ishii 2001). Unfortunately, the very scarce occurrence of ephyrae in our zooplankton samples failed to identify the precise timing of ephyra liberation from benthic polyps, which also remained undiscovered despite our scuba diving searches. Hence, it is still uncertain when and where medusa recruits come from for $A$. aurita population in the Honjo District.

Compared to 2005, the medusa population size was much smaller in 2006, but vice versa for medusa body size (Fig. 5), indicating population density effect (Schneider \& Behrends 1998). Such an annual variation in the occurrence of medusae has been noticed by a local fisherman ( $\mathrm{S}$. Nakashima, personal communication), who has been operating set-net fisheries in the Honjo District for $>50$ years. He also mentioned that medusae can persist during warm and mild winters and they tend to be more abundant in the following summer. The 2005-2006 winter was very severe; average local air temperature in December 2005 was $4.0^{\circ} \mathrm{C}$, while the corresponding average for the previous 10 years was $7.0^{\circ} \mathrm{C}$ (Meteorological Agency of Japan). An unusually rapid decline of water temperature to the annual minimum $\left(3.2^{\circ} \mathrm{C}\right.$ in January 2006) might hamper the overwintering of medusae as well as recruitment of a new population.

Uye et al. (2004) reported that due to sufficient phytoplankton food supply (average chlorophyll $a$ concentration: $4.7 \mu \mathrm{g} \mathrm{L}^{-1}$ ), the Honjo District is very productive for mesozooplankton; the average biomass and production rate were $71.0 \mathrm{mg} \mathrm{C} \mathrm{m}^{-3}$ and $17.6 \mathrm{mg} \mathrm{C} \mathrm{m}^{-3} \mathrm{~d}^{-1}$, respectively, during a two-year survey from 1997 to 1999 . The average mesozooplankton biomass $\left(60.5 \mathrm{mg} \mathrm{C} \mathrm{m}^{-3}\right)$ was similar to that of Uye et al. (2004) but the average production rate (32.4 $\mathrm{mg} \mathrm{C} \mathrm{m}{ }^{-3} \mathrm{~d}^{-1}$ ) was higher in our study. The predominance of bivalve larvae in our plankton samples boosted the mesozooplankton production rate, since small-sized bivalve larvae have higher specific growth rates $\left(g=0.4-1.0 \mathrm{~d}^{-1}\right)$ than copepods $\left(g=0.05-0.5 \mathrm{~d}^{-1}\right)$. During the warm period from June to November, 2005, the average medusa biomass $\left(58.8 \mathrm{mg} \mathrm{C} \mathrm{m}^{-3}\right)$ was equivalent to the average mesozooplankton biomass $\left(56.2 \mathrm{mg} \mathrm{Cm}^{-3}\right)$, demonstrating that $A$. aurita was certainly the most dominant species in the zooplankton community in the Honjo District.

Sullivan et al. (1994) reported that slow swimming prey such as hydromedusae and barnacle larvae were more vulnerable to predation by A. aurita. Graham \& Kroutil (2001) also demonstrated that small copepods were more vulnerable than large a copepods $(>1 \mathrm{~mm})$ since the latter has a higher escape ability. Zooplankton appearing in the Honjo District almost entirely consists of meso- and microzooplankton (Godhantaraman \& Uye 2003, Uye et al. 2004, present study) and hence they may be highly vulnerable. In fact, 5 major prey taxa (i.e. Oithona davisae, Acartia hudsonica, A. sinjiensis, bivalve larvae and gastropod larvae) were ingested in an almost non-selective manner (Fig. 7).

The mesozooplankton ingestion rates by a medusa determined in the Honjo District ranged from 0.06 to $28.9 \mathrm{mg} \mathrm{C}$ medusa $^{-1} \mathrm{~d}^{-1}$, which were similar to those reported in previous studies (i.e. $8-15 \mathrm{mg} \mathrm{C}$ medusa $^{-1} \mathrm{~d}^{-1}$ in Kiel Bight, Schneider \& Behrends 1994, 2.2-22.8 mg C medusa ${ }^{-1} \mathrm{~d}^{-1}$ in Tokyo Bay, Ishii \& Tanaka 2001, $6.07 \mathrm{mg} \mathrm{C}$ medusa $^{-1}$ $\mathrm{d}^{-1}$ in the Inland Sea of Japan, Uye \& Shimauchi 2005). Previous studies estimated the predation impacts by Aurelia medusa populations on zooplankton communities in the field, although different methods were employed depending on the study; the results are summarized in Table 1. An extremely high predation impact was reported by Olesen (1995) in Kertinge Nor, a brackish-water fjord in Denmark, where the A. aurita population ingested $351 \%$ of the rotifer biomass per day. In Kiel Bight, Germany, the medusa predation impact was equivalent to $64 \%$ of daily zooplankton secondary production (Schneider \& Behrends 1994). In Tokyo Bay, the predation pressure was estimated to vary from 5 to $162 \%$ of the zooplankton biomass per day (Kinoshita et al. 2006). In the Inland Sea of Japan, it was estimated to be $26 \%$ of the zooplankton biomass per day (Uye \& Shimauchi 2005). In contrast, the predation impacts re- 
ported by Purcell (2003) in Prince William Sound, Alaska, and Barz \& Hirche (2005) in Bomholm Basin, the Baltic Sea, were low ( $<$ ca. $8 \%$ of zooplankton biomass per day). In the Honjo District, the highest predation impact was recorded on 1 November 2005, when the A. aurita population (biomass: $81.4 \mathrm{mg} \mathrm{C} \mathrm{m}^{-3}$ ) ingested $29 \%$ of the mesozooplankton biomass $\left(31.7 \mathrm{mg} \mathrm{C} \mathrm{m}^{-3}\right)$ per day and $47 \%$ of the daily production rate $\left(19.8 \mathrm{mg} \mathrm{C} \mathrm{m}^{-3} \mathrm{~d}^{-1}\right)$. The corresponding average impacts between June and November 2005 were 8.9 and $13.0 \%$, respectively.

In conclusion, in a brackish-water lake called the Honjo District, $A$. aurita medusae occurred only in warm seasons, and in terms of biomass this species was the most dominant component of the zooplankton community. All major taxa of mesozooplankton were equally vulnerable to this gelatinous predator, and the predation pressure by the medusa population was highest in autumn. However, no significant top-down control by A. aurita was observed since the zooplankton biomass did not decrease concurrently. Mesozooplankton production potential might surpass the predation loss. This further suggests that $A$. aurita medusae might not be food-limited but their seasonal population fluctuation might be affected primarily by physical parameters such as temperature and deoxygenation in this eutrophic lake.

\section{Acknowledgements}

We thank Mr. Y. Mishiro for providing a motorboat for our sampling in the Honjo District and Miss M. Hayashi for help in zooplankton identification. This study was partially supported by a research grant from the Japan Society for the Promotion of Science (JSPS, no. 16405001) and the Agriculture, Forestry and Fisheries Research Council (POMAL-STOPJELLY Project).

\section{References}

Arai MN (2001) Pelagic coelenterates and eutrophication: a review. Hydrobiologia 451: 69-87.

Barz K, Hirche HJ (2005) Seasonal development of scyphozoan medusae and the predatory impact of Aurelia aurita on the zooplankton commuity in the Bornholm Basin (central Baltic Sea). Mar Biol 147: 465-476.

Brodeur RD, Sugisaki H, Hunt GL Jr (2002) Increases in jellyfish biomass in the Bering Sea: implications for the ecosystem. Mar Ecol Prog Ser 233: 89-103.

Dawson MN (2003) Macro-morphological variation among cryptic species of the moon jellyfish, Aurelia (Cnidaria: Scyphozoa). Mar Biol 143: 369-379.

Dawson MN, Martin LE (2001) Geographic variation and ecological adaptation in Aurelia (Scyphozoa, Semaeostomeae): some implications from molecular phylogenetics. Hydrobiologia 451: 259-273.

Godhantaraman N, Uye S (2003) Geographical and seasonal variations in taxonomic composition, abundance and biomass of microzooplankton across a brackish-water lagoonal system of
Japan. J Plankton Res 25: 465-482.

Graham, WM, Kroutil RM (2001) Size-based prey selectivity and dietary shifts in the jellyfish, Aurelia aurita. J Plankton Res 23: 67-74.

Hansson LJ, Moeslund O, Kiorboe T, Riisgård HU (2005) Clearance rates of jellyfish and their potential predation impact on zooplankton and fish larvae in a neritic ecosystem (Limfjorden Denmark). Mar Ecol Prog Ser 304: 117-131.

Ishii H, Tanaka F (2001) Food and feeding of Aurelia aurita in Tokyo Bay with an analysis of stomach contents and a measurement of digestion time. Hydrobiologia 451: 311-320.

Kawahara M, Uye S, Ohtus K, Iizumi H (2006) Unusual population explosion of the giant jellyfish Nemopilema nomurai (Scyphozoa: Rhizostomeae) in East Asian waters. Mar Ecol Prog Ser 307: 161-173.

Kinoshita J, Hiromi J, Yamada Y (2006) Abundance and biomass of Scyphomedusae, Aurelia aurita and Chrysaora melanaster, and Ctenophora, Bolinopsis mikado, with estimation of their feeding impact on zooplankton in Tokyo Bay, Japan. J Oceanogr 62: 607-615.

Koike F, Aizaki M, Seike Y, Akiba M, Okumura M, Fujinaga K (1999) Surface water exchange rate of the Honjo area in Lake Nakaumi estimated from salinity change. Laguna 6: 19-25. (in Japanese with English abstract)

Kuwabara R (1969) Ecological study of medusa Aurelia aurita Lamark-II. Distribution and biomass of Aurelia aurita in Lake Hamana in summer 1965. Bull Mar Biol Stn Asamushi 13: 193-199. (in Japanese with English abstract)

Kuwabara R, Sato S, Noguchi N (1969) Ecological studies on the medusae, Aurelia aurita Lamark-I. Distribution of Aurelia in the north-eastern region of Tokyo Bay in summer of 1966 and 1976. Bull Jpn Soc Sci Fish 35: 156-162. (in Japanese with English abstract)

Lindahl O, Hernroth L (1983) Phyto-zooplankton community in coastal waters of western Sweden- an ecosystem off balance. Mar Ecol Prog Ser 10: 119-126.

Mills CE (2001) Jellyfish blooms: are populations increasing globally in response to changing ocean conditions? Hydrobiologia 451: 55-68.

Miyake H, Iwao K, Kakinuma Y (1997) Life history and environment of Aurelia aurita. South Pacific Study 17: 273-285.

Möller H (1980) Scyphomedusae as predators and food competitors of larval fish. Meeresforschung 28: 90-100.

Olesen NJ (1995) Clearance potential of jellyfish Aurelia aurita, and predation impact on zooplankton in a shallow cove. Mar Ecol Prog Ser 63: 63-72.

Omori M, Ishii H, Fujinaga A (1995) Life history strategy of $A u$ relia aurita (Cnidaria, Scyphomedusae) and its impact on the zooplankton community of Tokyo Bay. ICES J Mar Sci 52: 597-603.

Pagès F, González HE, Ramón M, Sobarzo M, Gili J-M (2001) Gelatinous zooplankton assemblages associated with water masses in the Humboldt Current System, and potential predatory impact. Mar Ecol Prog Ser 210: 13-24.

Pearre Jr S (1982) Estimating prey preference by predators: use of various indices, and a proposal of another based on $\chi^{2}$. Can $\mathrm{J}$ Fish Aquat Sci 39: 914-923.

Purcell JE (2003) Predation on zooplankton by large jellyfish, $A u$ - 
relia labiata, Cyanea capillata and Aequorea aequorea, in Prince William Sound, Alaska. Mar Ecol Prog Ser 246: 137-152.

Purcell JE (2005) Climate effects on formation of jellyfish and ctenophore blooms: a review. J Mar Biol Ass UK 85: 461-476.

Purcell JE, Arai MN (2001) Interactions of pelagic cnidarians and ctenophores with fishes: a review. Hydrobiologia 451: 27-44.

Purcell JE, Sturdevant MV (2001) Prey selection and dietary overlap among zooplanktivorous jellyfish and juvenile fishes in Prince William Sound, Alaska. Mar Ecol Prog Ser 210: 67-83.

Purcell JE, Uye S, Lo W-T (2007) Anthropogenic causes of jellyfish blooms and their direct consequence for humans: a review. Mar Ecol Prog Ser 350: 153-174.

Rajagopal S, Nair KVK, Azariah J (1989) Some observations on the problem of jelly fish ingress in a power station cooling system at Kalpakkam, east coast of India. Mahasagar 22: 151-158.

Schneider G, Behrends G (1994) Population dynamics and the trophic role of Aurelia aurita medusae in Kiel Bight and western Baltic. ICES J Mar Sci 51: 359-367.

Schneider G, Behrends G (1998) Top-down control in a neritic plankton system by Aurelia aurita medusae- a summary. Ophelia 48: 71-82.

Sullivan BK, Garcia JR, Klein-MacPhee G (1994) Prey selection by the scyphomedusan predator Aurelia aurita. Mar Biol 121: 335-341.

Uye S (1982) Length-weight relationships of important zooplankton from the Inland Sea of Japan. J Oceanogr 38: 149-158.
Uye S, Fujii N, Takeoka H (2003) Unusual aggregations of the scyphomedusa Aurelia aurita in coastal waters along western Shikoku. Plankton Biol Ecol 50: 17-21.

Uye S, Nakai S, Aizaki M (2004) Potential use of extremely high biomass and production rate of copepods in an enclosed brackish water body in Lake Nakaumi, Japan, for mass seed production of fishes. Zool Stud 43: 165-172.

Uye S, Shimauchi H (2005) Population biomass, feeding, respiration and growth rates, and carbon budget of the scyphomedusa Aurelia aurita in the Inland Sea of Japan. J Plankton Res 27: 237-248.

Uye S, Shimazu T (1997) Geographical and seasonal variations in abundance, biomass and estimated production rates of mesoand macrozooplankton in the Inland Sea of Japan. J Oceanogr 53: 529-538.

Uye S, Ueta Y (2004) Recent increase of jellyfish populations and their nuisance to fisheries in the Inland Sea of Japan. Bull Jpn Soc Fish Oceanogr 68: 9-19.

Watanabe T, Ishii H (2001) In situ estimation of ephyrae liberation from polyps of Aurelia aurita using settling plates in Tokyo Bay, Japan. Hydrobiologia 451: 247-258.

Yasuda T (1969) On the occurrence of the jellyfish ephyrae in Tanjoura Bay, Fukui Prefecture. Aquaculture 17: 33-39. (in Japanese with English abstract)

Yasuda T (1983) Studies on the common jellyfish Aurelia aurita (Linne). Jpn Fish Resource Conserv Assoc, Tokyo, 189 pp. (in Japanese with English abstract) 